\title{
COMPARISON OF HERBAL MOUTHWASH WITH COMMERCIALLY AVAILABLE 0.2\% CHLORHEXIDINE AND 2\% BETADINE MOUTHWASHES IN PATIENTS AFTER STAGE-1 IMPLANT SURGERY
}

\author{
JEMBULINGAM SABARATHINAM ${ }^{1}$, DEEPAK NALLASWAMY ${ }^{1}$, MURALIDHARAN NP ${ }^{2}$ \\ ${ }^{1}$ Department of Prosthodontics, Saveetha Dental College, Chennai 77, Tamil Nadu, India. ${ }^{2}$ Department of Microbiology, Saveetha Dental \\ College, Chennai 77, Tamil Nadu, India. Email: drjembu@gmail.com
}

Received: 15 February 2017, Revised and Accepted: 11 August 2017

\section{ABSTRACT}

Objective: The objective of the current study is to assess the antibacterial efficiency of an herbal mouthwash (clove and neem) against $0.2 \%$ chlorhexidine and $2 \%$ betadone mouthwash in patients who have undergone Stage- 1 implant surgery.

Methods: 30 patients undergoing implant surgery (Stage-1) were divided into 3 groups and were given 3 different mouthwashes. The patient was recalled after 15 days. Swab samples from the site of implant were taken after 15 days and cultured. The results were tabulated.

Results: $0.2 \%$ chlorhexidine and $2 \%$ bernadine were found to have better antibacterial efficiency than herbal mouthwash ( $p>0.05)$.

Conclusion: The herbal mouthwash consisting of neem and clove was not efficient in killing microbes immediately after Stage- 1 implant surgery when compared to $0.2 \%$ chlorhexidine and $2 \%$ bernadine.

Keywords: Mouthwashes, Herbal, Implants, Efficiency, Stage-1 Implant Surgeries.

(C) 2017 The Authors. Published by Innovare Academic Sciences Pvt Ltd. This is an open access article under the CC BY license (http://creativecommons. org/licenses/by/4. 0/) DOI: http://dx.doi.org/10.22159/ajpcr.2017.v10i12.17786

\section{INTRODUCTION}

Dental implants, an inevitable part of modern dentistry, are used widely to replace the missing teeth and to restore the function and aesthetics of the teeth $[1,2]$. Moreover, the success of the implant depends on various factors of which inflammation is a major factor [3,4]. Since the dental implant which is foreign material placed into the bone of the individual, it has the ability to increase colonies of bacteria in and around the implant region and cause many problems and ultimately failure of the implants itself [5].

Recent studies in vivo conditions had proved that bacterial accumulation has started within 30 minutes after the placement of implant [6]. Other studies proved that on exposure of the dental implant to oral cavity has increased the microbial count of specific species of bacteria such as Streptococci [5]. Even anaerobic bacteria showed an increased count in $48 \mathrm{hrs}$ [7]. Many opportunistic periodontal bacteria such as Actionmycetemcomitans, Peptostreptococcus microbes and Fusobacterium nucleatum are responsible for the peri-implantitis in edentulous patients [8].

About $10 \%$ of the implants placed resulted in failure due to bacterial infections. Bacteria-associated infections in implants include periimplantitis and peri-implant mucositis [9]. These microbes are also responsible for increasing the bone loss surrounding the dental implants which also contributes majorly to the failure of implants [10].

The aim of the current study is to assess the antibacterial efficacy of an herbal mouthwash (clove and neem) against $0.2 \%$ chlorhexidine and $2 \%$ betadine mouthwash in patients who have undergone Stage- 1 implant surgery.

\section{METHODS}

\section{Sample and setting}

A total of 30 patients who had undergone Stage- 1 implant surgery in the Implantology department of Saveetha dental college were recruited for this study from July 2016 to December 2016.The patients were divided into three groups based on the type of mouthwash they were given.

\section{Study groups}

- Group A: $0.2 \%$ chlorhexidine was given for 10 patients.

- Group B: $2 \%$ betadine was given for 10 patients.

- Group C: Herbal mouthwash was given for 10 patients.

Ethical consideration

The research protocol for this study was submitted to the scientific review board of Saveetha dental college and Hospitals and Institutional Human ethical committee. Necessary permission was obtained to conduct this study; moreover, a written informed consent was obtained from patient before proceeding with the study.

\section{Inclusion criteria}

- Patients who have undergone Stage-1 surgery.

- Patients without any other lesion in the oral cavity.

- Patients with single implant and adjacent tooth structure near the implant site.

\section{Exclusion criteria}

- Patients having systemic diseases.

- Patients with any lesions in the oral cavity.

- Patient without adjacent tooth structureor posterior most tooth.

Patients were given three mouthwashes $0.2 \%$ chlorhexidine, $2 \%$ betadine, and herbal mouthwash and were advice to use it once at morning and once at night $20 \mathrm{ml}$ for 30 seconds.

\section{Culturing techniques}

Samples were collected using a sterile cotton swab which was moistened and swab was collected from the implant site and transported. The sample was cultured in brain heart infusion agar using spread plate culture method and the plates were incubated for $24 \mathrm{hrs}$ and the colony forming units (CFU) was counted manually and tabulated. 
Statistical analysis

The data were collected and statistical analyzed by one-way ANOVA post hoc bonferroni Pair wise comparison in SPSS (version 20).

\section{RESULTS}

The manually counted colony forming units were using Statistical package for social sciences (version 20).

Group C had the maximum bacterial count (10036) followed by Group A (3308) and Group B (2969)

There was a significant difference between Group A and Group B $(\mathrm{p}<0.05)$ (one-way ANOVA post hoc bonferroni pairwise comparison).

There was no significant difference between Group A and Group C, Group B and Group C ( $>>0.05)$ (one-way ANOVA post hoc bonferroni pairwise comparison).

There was a significant difference.

Table 1 showing a significant difference in the bacterial colony forming unit cultures from samples collected from patients using a, $\mathrm{b}$, and $\mathrm{c}$ mouthwashes. $\mathrm{p}<0.001$ one-way ANOVA, bonferroni pairwise comparisons Fig 1.

Table 2 showing a significant difference in the bacterial colony forming unit cultures from samples collected from patients using a, b, and c mouthwashes. $p<0.001$ where $p$ value is lesser than 0.001 from the result one-way ANOVA. Post hoc bonferroni pair wise comparison.

\section{DISCUSSIONS}

In our current study, there was maximum bacterial load present in patients using herbal mouthwash when compared to patients using chemical mouthwash such as chlorhexidine and betadine. Betadine was found to be more effective against the bacteria in comparison to patients using chlorhexidine.

There are various factors which could have influenced the results of the study.

\section{The regularity of the use of mouthwash}

The regularity of the use of the mouthwash could have influenced the results of the study, as irregular use of the mouthwash could have

Table 1: Comparison of the $1 \%$ betadine, $0.2 \%$ chlorohexidine, and herbal mouthwash by one-way ANOVA where $p<0.05$

\begin{tabular}{llllll}
\hline Test groups & N & Mean & SD & SE & Significance \\
\hline $0.2 \%$ chlorhexidine & 10 & 3373 & 3308 & 1096 & 0.00 \\
2\% betadine & 10 & 1646 & 2969 & 938 & \\
Herbal mouthwash & 10 & 10036 & 1051 & 332 & \\
\hline
\end{tabular}

SD: Standard deviation, SE: Standard error increased the bacterial load in the patient's oral cavity. However, the patients were reminded periodically about the use of mouthwash in specific time and particular quantity.

\section{Dietary habits}

Dietary habits of the patients are potential factors in influencing the results of the study as increased carbohydrate consumption; increase the sugar levels in oral cavity which could have elevated the microbial population in the oral cavity.

\section{Bacterial profile}

Bacterial profile of the patients would have influenced the study as some of the patients would have already had a high bacterial count in nature, which might have given the high bacterial count in the study groups. However, in the current study, the pre-operative bacterial count was not recorded which proves to be a limitation.

\section{Immunity of the patient}

Immunity of the patient is also one of the vulnerable factors which could have influenced the study as immunocompromised patients would have increased microbial count when compared to normal patients. Immunocompromised could be due to placement any other artificial valve or implants in the body for many systemic diseases. However, in our current study, patients with systemic diseases were excluded from the study, so that this factor could have not influenced the study.

- Studies have been conducted on herbal mouthwashes [11-13] which are proven to be beneficial in various aspects of dentistry. However, in our current study, the preoperative bacterial count were not recorded; hence, further research on comparison of pre-operative and post-operative bacterial count may enlighten the scope of the herbal mouthwashes.

\section{CONCLUSION}

The herbal mouthwash which consist of neem and clove ( $p>0.05)$ was not as effective in killing the microbes immediately after the

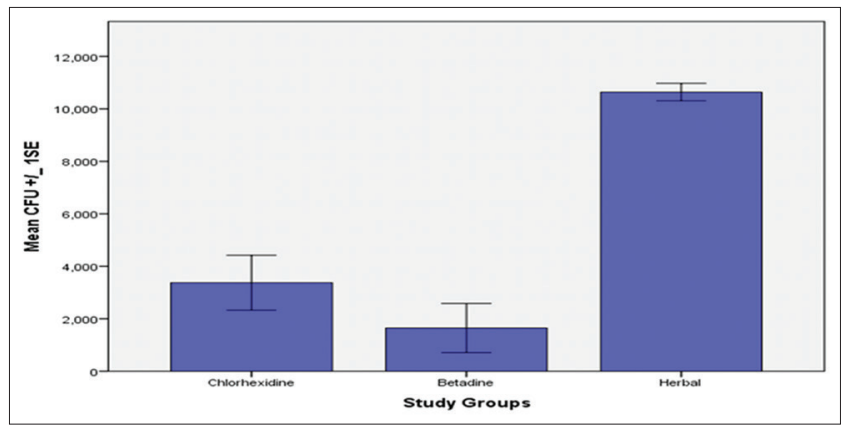

Fig. 1: Comparison of the colony forming units of $1 \%$ betadine, $0.2 \%$ chlorhexidine, and herbal mouthwash (one-way ANOVA bonferroni test)

Table 2: Comparison of the $1 \%$ betadine, $0.2 \%$ chlorohexidine, and herbal mouthwash by one-way ANOVA where p<0.05

\begin{tabular}{|c|c|c|c|c|c|c|}
\hline \multicolumn{7}{|c|}{$\begin{array}{l}\text { Dependent variable: CFU } \\
\text { Bonferroni }\end{array}$} \\
\hline \multirow[t]{2}{*}{ (I) Group } & \multirow[t]{2}{*}{ (J) Group } & \multirow[t]{2}{*}{ Mean difference (I-J) } & \multirow[t]{2}{*}{ SE } & \multirow[t]{2}{*}{ Significant } & \multicolumn{2}{|c|}{$95 \%$ confidence interval } \\
\hline & & & & & Lower bound & Upper bound \\
\hline Chlorhexidine & $\begin{array}{l}\text { Betadine } \\
\text { Herbal } \\
\text { Chlorohexidine } \\
\text { Herbal } \\
\text { Chlorohexidine } \\
\text { Herbal }\end{array}$ & 1726.600 & $\begin{array}{l}1179.024 \\
1179\end{array}$ & $\begin{array}{l}0.464 \\
0.000\end{array}$ & $\begin{array}{l}-1282.81 \\
-10275.91\end{array}$ & $\begin{array}{l}4736.01 \\
-4257.09\end{array}$ \\
\hline
\end{tabular}

${ }^{*}$ The mean difference is significant at the 0.05 level. CFU: Colony forming units. The significant value is 0.05 
Stage-1 implant surgery when compared with $0.2 \%$ chlorhexidine and $2 \%$ betadine. Moreover, $2 \%$ betadine $(\mathrm{p}<0.05)$ was found to be more effective than $0.2 \%$ chlorhexidine when the 2 mouthwashes was compared. Hence, use of $2 \%$ betadine over chlorhexidine is recommended to patients to avoid implant failure due to microbial contamination.

\section{REFERENCES}

1. Guckes AD, Scurria MS, Shugars DA. A conceptual framework for understanding outcomes of oral implant therapy. J Prosthet Dent 1996;75(6):633-9.

2. Brånemark PI, Svensson B, van Steenberghe D. Ten-year survival rates of fixed prostheses on four or six implants ad modum Brånemark in full edentulism. Clin Oral Implants Res 1995;6(4):227-31.

3. Quirynen M, De Soete M, van Steenberghe D. Infectious risks for oral implants: A review of the literature. Clin Oral Implants Res 2002;13(1):1-19.

4. Scarano A, Piattelli M, Caputi S, Favero GA, Piattelli A. Bacterial adhesion on commercially pure titanium and zirconium oxide disks: An in vivo human study. J Periodontol 2004;75(1):292-6.

5. Pye AD, Lockhart DE, Dawson MP, Murray CA, Smith AJ. A review of dental implants and infection. J Hosp Infect 2009;72(2):104-10.
6. Zitzmann NU, Abrahamsson I, Berglundh T, Lindhe J. Soft tissue reactions to plaque formation at implant abutments with different surface topography. An experimental study in dogs. J Clin Periodontol 2002;29(5):456-1.

7. Subramani K, Jung RE, Molenberg A, Hammerle CH. Biofilm on dental implants: A review of the literature. Int J Oral Maxillofac Implants 2009;24(4):616-26.

8. Shahabouee M, Rismanchian M, Yaghini J, Babashahi A, Badrian H, Goroohi H. Microflora around teeth and dental implants. Dent Res J (Isfahan) 2012;9(2):215-20.

9. Alcoforado GA, Rams TE, Feik D, Slots J. Microbial aspects of failing Osseo integrated dental implants in humans. J Parodontol 1991;10(1):11-8

10. Mombelli A, van Oosten MA, Schurch E Jr, Land NP. The microbiota associated with successful or failing Osseo integrated titanium implants. Oral Microbiol Immunol 1987;2(4):145-1.

11. Kritivasan S, Muralidharan NP. Antimicrobial activity of fruit juices on oral bacteria. Int J Pharm Sci Res 2017;8(1):289-3

12. Lavanya J, Selvam SP, Priya MJ, Jacinth AP, Aradana M. Antioxidant and antimicrobial activity of selected medicinal plants against human oral pathogens. Int J Pharm Pharm Sci 2016;8(9):71-8.

13. Singgih M, Damayanti S, Pandjaitan N. Antimicrobial activity of standardized Piper betel extract and its mouthwash preparation. Int $\mathrm{J}$ Pharm Pharm Sci 2014;6(7):243-6. 